\title{
Retraction
}

\section{Retracted: Design of UWB Filter with WLAN Notch}

\section{International Journal of Antennas and Propagation}

Received 6 August 2013; Accepted 6 August 2013

Copyright (C) 2013 International Journal of Antennas and Propagation. This is an open access article distributed under the Creative Commons Attribution License, which permits unrestricted use, distribution, and reproduction in any medium, provided the original work is properly cited.

This article has been retracted as it is essentially identical in content with the published article "Design of Compact UWB Band Pass Filter with WLAN Notch," by Satish Chand Gupta and Mithilesh Kumar, published in the Proceedings of the National Conference on Trends in Signal Processing \& Communication (TSPC'11) 10-12 March, 2011 at Bhagwant Institute of Technology, Muzaffarnagar, India [1].

\section{References}

[1] H. Kumar and M. Upadhayay, "Design of UWB filter with WLAN notch," International Journal of Antennas and Propagation, vol. 2012, Article ID 971097, 4 pages, 2012. 